\title{
KARAKTERISTIK ROTI TAWAR DENGAN SUBSTITUSI TEPUNG SORGUM (Sorghum bicolor (L) MOENCH) TERFERMENTASI DAN TANPA FERMENTASI
}

\section{CHARACTERISTICS OF WHITE BREAD WITH FERMENTED AND UNFERMENTED SORGHUM FLOUR (Sorghum bicolor (L) MOENCH)}

\author{
Ardhea Mustika.S ${ }^{1)}$, Linda Kurniawati ${ }^{1)}$, Akhmad Mustofa ${ }^{1)}$ \\ 1) Fakultas Teknologi dan Industri Pangan, Universitas Slamet Riyadi, Surakarta \\ email: ardheamustika@gmail.com
}

\begin{abstract}
This research was aimed to determine the appropriate concentration of fermented and unfermented sorghum flour for bread making which received by the panelists. Sorghum flour was naturally fermented and then dried with cabinet dryer at $60^{\circ} \mathrm{C}$ for $8 \mathrm{~h}$. Substitution of sorghum flour either fermented and unfermented performed at various concentration i.e 10\%, 20\%, 30\% and 40\%. Organoleptic test results showed that white bread accepted by panelists was subtituted with fermented and unfermented sorghum flour in concentration of $10 \%$ and $20 \%$. White bread with fermented sorghum flour substitution of $10 \%$ and $20 \%$ have moisture content of $28.702 \%$ and $34.392 \%$, while white bread with unfermented sorghum flour has moisture content $28.660 \%$ and $31.857 \%$. Ash content of white bread with fermented sorghum flour $10 \%$ and $20 \%$ were $0.823 \%$ and $0.638 \%$, while white bread with unfermented sorghum flour $10 \%$ and $20 \%$ have ash content of $0.830 \%$ and $0.718 \%$. Fiber content of white bread subtituted with $10 \%$ and $20 \%$ fermented sorghum flour was $3.375 \%$ and $4,206 \%$ respectively whereas white bread with $10 \%$ and $20 \%$ unfermented sorghum flour have fiber content $3.008 \%$ and $3.873 \%$.
\end{abstract}

Key words: fermentation, sorghum flour, white bread

ABSTRAK

Penelitian ini bertujuan untuk mengetahui konsentrasi substitusi tepung sorgum yang telah mengalami fermentasi spontan dan tanpa fermentasi untuk pembuatan roti tawar yang diterima oleh panelis. Tepung sorgum difermentasi secara spontan kemudian dikeringkan dengan cabinet dryer pada suhu $60{ }^{\circ} \mathrm{C}$ selama 8 jam. Substitusi tepung sorgum yang difermentasi dan tanpa fermentasi dilakukan pada variasi konsentrasi 10\%, 20\%, $30 \%$ dan $40 \%$. Hasil uji organoleptik menunjukkan bahwa roti tawar yang dapat diterima panelis adalah roti tawar dengan konsentrasi substitusi tepung sorgum $10 \%$ dan $20 \%$ baik tepung sorgum dengan fermentasi maupun tanpa fermentasi. Secara kimia roti tawar dengan substitusi tepung sorgum terfermentasi $10 \%$ dan $20 \%$ memiliki kadar air 28,702\% dan 34,392\%, sedangkan roti tawar dengan tepung sorgum tanpa fermentasi memiliki kadar air $28,660 \%$ dan $31,857 \%$. Kadar abu roti tawar dengan tepung sorgum terfermentasi $10 \%$ dan $20 \%$ adalah $0,823 \%$ dan $0,638 \%$ sedangkan roti tawar dengan tepung sorgum tanpa fermentasi $10 \%$ dan $20 \%$ memiki kadar abu 0,830\%dan 0,718\%. Kadar serat produk roti tawar dengan substitusi tepung sorgum cukup tinggi yaitu 3,375\% dan 4, 206\% untuk substitusi 10\% dan 20\% tepung sorgum terfermentasi, sedangkan tanpa fermentasi kadar serat substitusi $10 \%$ dan $20 \%$ adalah $3,008 \%$ dan $3,873 \%$.

Kata kunci: fermentasi, tepung sorgum, roti tawar

\section{PENDAHULUAN}

Roti tawar merupakan salah satu produk pangan yang cukup populer di dunia. Berdasarkan Data Sosial Ekonomi Nasional (Susenas) tahun 2005, di Indonesia konsumsi roti tawar nasional sekitar 460 juta bungkus, angka ini meningkat sebesar $61 \%$ pada tiga tahun berikutnya sehingga menjadi sekitar 742 juta bungkus (Rahardian, 2010). Roti tawar banyak disukai masyarakat karena memiliki beberapa manfaat diantaranya bergizi, mengenyangkan dan kemudahan dalam preparasi dan konsumsi.
Tepung terigu sebagai bahan utama dalam pembuatan roti tawar memiliki peranan besar dalam tingkat pengembangan roti. Tingginya konsumsi roti tawar akan meningkatkan konsumsi gandum di Indonesia. Sedangkan gandum sendiri kurang cocok ditanam di Indonesia, sehingga kebutuhan gandum di Indonesia dipenuhi dengan impor. Berdasarkan data dari Badan Pusat Statistik (BPS), impor gandum segar di Indonesia dari tahun ke tahun selalu mengalami peningkatan. Pada tahun 2009 impor gandum segar mencapai 4.666.418 ton, meningkat menjadi 4.824 .049 ton pada tahun 2010, dan menjadi 5.648.065 ton pada tahun 
2011. Oleh karena itu perlu adanya substitusi bahan lainnya sehingga dapat mengurangi penggunaan tepung terigu dalam pembuatan roti tawar.

Sorgum (Sorghum bicolor (L.) Moench.) merupakan salah satu serealia lokal yang berpotensi digunakan sebagai substituen gandum dalam pembuatan roti tawar. Sorgum merupakan sumber serealia kelima di dunia setelah beras, jagung, gandum dan barley yang memiliki kandungan gizi yang cukup tinggi sebagai sumber karbohidrat, protein, vitamin dan beberapa mineral penting (Ibrahim, et.al., 2005). Kadar protein sorgum setara dengan protein pada gandum, namun keberadaan protein sorgum terikat oleh pati sehingga tingkat kecernaannya rendah. Perendaman tepung sorgum (fermentasi spontan) sebelum pengolahan menjadi bahan pangan merupakan salah satu cara untuk meningkatkan kecernaan protein sorgum. Beberapa penelitian menyebutkan fermentasi tepung sorgum sebelum pengolahan dapat meningkatkan kecernaan pati dan protein sorgum (Pranoto, et.al., 2013). Dengan upaya substitusi tepung sorgum terfermentasi dalam pembuatan roti tawar diharapkan akan mengurangi impor gandum Indonesia.

Penelitian ini bertujuan untuk mengetahui prosentase substitusi tepung sorgum terfermentasi dan tanpa fermentasi pada pembuatan roti tawar yang dapat diterima (acceptable) oleh panelis serta mengetahui pengaruh substitusi tepung sorgum terfermentasi pada sifat kimia (kadar air, kadar abu, kadar serat kasar) roti tawar yang disubstitusi yang terpilih.

\section{Bahan}

\section{METODE PENELITIAN}

Bahan yang digunakan meliputi bahan utama dan bahan kimia untuk analisa. Bahan utama yang digunakan dalam penelitian ini adalah sorgum dan terigu serta bahan-bahan untuk membuat roti tawar antara lain $5 \mathrm{~g}$ susu skim $10 \mathrm{~g}$ mentega putih, $5 \mathrm{~g}$ gula, 3,75 g garam, $5,5 \mathrm{~g}$ yeast, $2 \mathrm{~g}$ bread improver dan $165 \mathrm{ml}$ air (dalam $250 \mathrm{~g}$ tepung komposit terigusorgum).

\section{Alat}

Alat yang digunakan dalam penelitian meliputi peralatan untuk pembuatan tepung sorgum dan fermentasi (perendaman) tepung sorgum, peralatan pembuatan roti tawar dan peralatan untuk analisa.

Penepungan sorgum menggunakan grinder, cabinet dryer dan ayakan. Peralatan pembuatan roti tawar meliputi timbangan roti, baskom mangkok, roller, mixer, loyang, profer dan Oven.

\section{Tahapan penelitian}

Tepung sorgum yang telah difermentasi dan tanpa fermentasi disubstitusikan pada pembuatan roti tawar dengan konsentrasi 10 , 20, 30 dan $40 \%$. Semua bahan pembuatan roti tawar dicampurkan dan dilakukan fermentasi pertama selama 30 menit dan fermentasi kedua selama 60 menit. Fermentasi adonan dilakukan pada suhu $37{ }^{\circ} \mathrm{C}$. Setelah fermentasi adonan kedua kemudian dilakukan pemanggangan pada suhu $190{ }^{\circ} \mathrm{C}$ selama 25 menit.

Semua sampel roti diujikan kepada panelis dengan metode scoring test untuk menilai kesukaan panelis terhadap produk roti tawar sorgum. Produk yang dapat diterima panelis kemuadian dianalisa kandungan kimianya meliputi kadar air, kadar abu dan kadar serat.

\section{HASIL DAN PEMBAHASAN}

\section{Uji Organoleptik}

Uji organoleptik yang dilakukan pada penelitian ini merupakan uji kesukaan (hedonic test) dengan metode scoring test. Dengan metode ini dapat diketahui sampel roti tawar dengan substitusi tepung sorgum pada konsentrasi berapa yang dapat diterima oleh panelis. Atribut sensoris yang diujikan pada pengujian ini meliputi warna, rasa, dan tekstur serta penilaian tingkat kesukaan secara keseluruhan panelis terhadap sampel roti tawar sorgum. Hasil pengujian tingkat kesukaan panelis dapat dilihat pada Tabel 1.

Dari hasil uji kesukaan diperoleh hasil rata-rata panelis lebih menyukai roti tawar dengan substitusi tepung sorgum maksimal $20 \%$ baik tepung sorgum yang difermentasi maupun tanpa fermentasi. Substitusi tepung sorgum diatas $20 \%$ menurunkan tingkat kesukaan panelis terhadap sampel roti tawar meskipun secara statistik tidak menunjukkan 
perbedaan nyata. Dari segi rasa dan tekstur, peningkatan kadar substitusi tepung sorgum pada roti tawar juga memberikan penurunan terhadap tingkat kesukaan.

\section{Kadar Air}

Pada penelitian ini pengujian kadar air hanya dilakukan pada sampel roti tawar yang disukai panelis atau memiliki skor yang tinggi yaitu pada substitusi tepung sorgum $10 \%$ dan $20 \%$ baik tepung sorgum yang difermentasi maupun tanpa fermentasi. Hasil analisis kadar air disajikan pada Tabel 2.

Dari Tabel 2 dapat dilihat ada peningkatan kadar air dengan bertambahnya konsentrasi substitusi tepung sorgum meskipun tidak berbeda nyata. Kenaikan kadar air dengan penambahan tepung sorgum diakibatkan oleh kadar protein tepung sorgum yang tinggi. Menurut Lowe (1943) protein lebih mudah mengikat air dibandingkan dengan pati.

Roti tawar yang disubstitusi dengan tepung sorgum yang difermentasi memiliki kadar air yang lebih tinggi meskipun peningkatan kadar air tersebut tidak berbeda nyata dengan roti tawar yang disubstitusi dengan tepung sorgum tanpa fermentasi.

Proses fermentasi mengakibatkan penurunan suhu gelatinisasi pati sehingga berdampak pada kenaikan viskositas adonan roti karena ada pemecahan granula pati menjadi granula yang lebih kecil sehingga lebih mudah mengikat air (Hidayah, 2010).

Kadar air roti tawar dengan substitus tepung sorgum pada penelitian ini masih masuk dalam kisaran SNI 01-3840-1995 roti tawar yaitu memiliki kadar air maksimal $40 \%$.

Tabel 1. Hasil Pengujian Tingkat Kesukaan Panelis terhadap Roti Tawar yang Disubstitusi dengan Tepung Sorgum

\begin{tabular}{|c|c|c|c|c|}
\hline \multirow{2}{*}{ Sampel roti tawar } & \multicolumn{4}{|c|}{ Parameter kesukaan } \\
\hline & Warna & Rasa & Tekstur & Kesukaan keseluruhan \\
\hline $0 \%$ (tanpa subtitusi) & $3,6^{\mathrm{b}}$ & $3,4^{b}$ & $3,4^{\mathrm{b}}$ & $3,6^{\mathrm{b}}$ \\
\hline $10 \%$ substitusi dengan fermentasi & $1,7^{\mathrm{a}}$ & $1,7^{\mathrm{a}}$ & $1,6^{\mathrm{a}}$ & $1,6^{\mathrm{a}}$ \\
\hline $10 \%$ substitusi tanpa fermentasi & $2,1^{\mathrm{a}}$ & $1,7^{\mathrm{a}}$ & $2,0^{\mathrm{a}}$ & $1,9^{\mathrm{a}}$ \\
\hline $20 \%$ substitusi dengan fermentasi & $1,9^{\mathrm{a}}$ & $1,3^{\mathrm{a}}$ & $2,3^{\mathrm{a}}$ & $1,6^{\mathrm{a}}$ \\
\hline $20 \%$ substitusi tanpa fermentasi & $1,4^{\mathrm{a}}$ & $1,4^{\mathrm{a}}$ & $1,8^{\mathrm{a}}$ & $1,4^{\mathrm{a}}$ \\
\hline $30 \%$ substitusi dengan fermentasi & $2,0^{\mathrm{a}}$ & $1,5^{\mathrm{a}}$ & $1,4^{\mathrm{a}}$ & $1,4^{\mathrm{a}}$ \\
\hline $30 \%$ substitusi tanpa fermentasi & $1,6^{\mathrm{a}}$ & $1,2^{\mathrm{a}}$ & $1,7^{\mathrm{a}}$ & $1,3^{\mathrm{a}}$ \\
\hline $40 \%$ substitusi dengan fermentasi & $2,3^{\mathrm{a}}$ & $1,0^{\mathrm{a}}$ & $1,2^{\mathrm{a}}$ & $1,2^{\mathrm{a}}$ \\
\hline $40 \%$ substitusi tanpa fermentasi & $2,0^{\mathrm{a}}$ & $1,3^{\mathrm{a}}$ & $1,3^{\mathrm{a}}$ & $1,2^{\mathrm{a}}$ \\
\hline
\end{tabular}

Tabel 2. Kadar air roti tawar dengan substitusi tepung sorgum dalam \% (wb)

\begin{tabular}{ccc} 
Konsentrasi tepung sorgum & Fermentasi & Non Fermentasi \\
\hline $10 \%$ & $28,702^{\mathrm{a}}$ & $28,660^{\mathrm{a}}$ \\
$20 \%$ & $34,392^{\mathrm{a}}$ & $31,857^{\mathrm{a}}$ \\
\hline Keterangan: - Angka yang diikuti huruf yang sama menunjukkan berbeda tidak nyata dengan uji Tukey 5\%
\end{tabular}


Tabel 3. Kadar Abu Roti Tawar dengan Substitusi Tepung Sorgum dalam \% (wb)

\begin{tabular}{ccc}
\hline $\begin{array}{c}\text { Konsentrasi tepung } \\
\text { sorgum }\end{array}$ & Fermentasi & Non Fermentasi \\
\hline $10 \%$ & $0,823^{\mathrm{a}}$ & $0,830^{\mathrm{a}}$ \\
$20 \%$ & $0,638^{\mathrm{a}}$ & $0,718^{\mathrm{a}}$ \\
\hline
\end{tabular}

Keterangan: - Angka yang diikuti huruf yang sama menunjukkan berbeda tidak nyata dengan uji Tukey 5\%

Tabel 4. kadar serat roti tawar dengan substitusi tepung sorgum dalam \% (wb)

\begin{tabular}{ccc}
\hline Konsentrasi tepung sorgum & Fermentasi & Non Fermentasi \\
\hline $10 \%$ & $3,375^{\text {a }}$ & $3,008^{\text {a }}$ \\
$20 \%$ & $4,206^{\text {a }}$ & $3,873^{\text {a }}$ \\
\hline
\end{tabular}

Keterangan: - Angka yang diikuti huruf yang sama menunjukkan berbeda tidak nyata dengan uji Tukey 5\%

\section{Kadar Abu}

Dari Tabel 3 dapat dilihat bahwa kadar abu roti tawar dengan substitusi $10 \%$ tepung sorgum yang difermentasi dan tanpa fermentasi tidak menunjukkan perbedaan nyata, sedangkan pada substitusi $20 \%$ terjadi peningkatan kadar abu pada roti tawar dengan tepung sorgum tanpa fermentasi meskipun peningkatan tersebut tidak signifikan. Hal ini menunjukkan selama fermentasi tepung sorgum, terjadi aktivitas mikrobia yang menggunakan mineral dalam tepung sehingga terjadi penurunan kadar abu tepung sorgum yang awalnya $1,40 \%$.

Peningkatan konsentrasi substitusi tepung sorgum menurunkan kadar abu meskipun tidak signifikan. Pada roti tawar dengan tepung sorgum yang difermentasi, substitusi $10 \%$ tepung memiliki kadar abu $0,823 \%$ sedangkan substitusi $20 \%$ memiliki kadar abu $0,638 \%$. Roti tawar dengan tepung sorgum tanpa fermentasi memiliki kadar abu yang lebih tinggi yaitu $0,830 \%$ untuk substitusi $10 \%$ dan $0,718 \%$ untuk substitusi $20 \%$.

\section{Kadar Serat Kasar}

Pada penelitian ini dilakukan analisa serat kasar pada roti tawar sorgum yang diterima panelis untuk mengetahui potensi produk ini sebagai pangan fungsional yang kaya serat. Tepung sorgum memiliki kandungan serat 4,23\% sedangkan terigu hanya mengandung serat kasar sebesar $0,3 \%$ sehingga diharapkan substitusi tepung sorgum pada produk roti tawar dapat memberikan asupan serat. Hasil analisis serat kasar dapat dilihat pada Tabel 4.

Kadar serat kasar roti tawar sorgum dengan substitusi tepung sorgum tanpa fermentasi lebih rendah dibanding roti tawar yang disubstitusi tepung sorgum terfermentasi meskipun tidak berbeda nyata. Substitusi tepung sorgum yang difermentasi menaikan kadar serat kasar roti tawar karena dengan fermentasi, pati dalam tepung sorgum mudah terakses sehingga lebih mudah tergelatinisasi pada proses pemanggangan. Setelah pemanggangan, pati yang tergelatinisasi tersebut mengalami retrogradasi sehingga membentuk pati yang resisten (resistant starch) yang merupakan salah satu serat pangan (Marsono, 2004). Peningkatan kadar substitusi tepung sorgum pada roti tawar sorgum meningkatkan kadar serat kasar meskipun peningkatannya tidak signifikan. Peningkatan kadar serat ini disebabkan karena tepung sorgum memiliki kadar serat yang lebih tinggi dibanding terigu sehingga peningkatan substitusi tentu saja menaikkan kadar serat kasar pada produk roti tawar. Dengan demikian, substitusi tepung sorgum pada produk roti tawar dapat meningkatkan asupan serat meskipun konsentrasi substitusi yang dapat diterima panelis maksimal $20 \%$.

\section{KESIMPULAN}

Hasil uji organoleptik menunjukkan bahwa roti tawar yang dapat diterima panelis adalah roti tawar dengan konsentrasi substitusi tepung sorgum $10 \%$ dan $20 \%$ baik tepung sorgum dengan fermentasi maupun 
tanpa fermentasi. Secara kimia roti tawar dengan substitusi tepung sorgum terfermentasi $10 \%$ dan $20 \%$ memiliki kadar air $28,702 \%$ dan $34,392 \%$, sedangkan roti tawar dengan tepung sorgum tanpa fermentasi memiliki kadar air 28,660\% dan $31,857 \%$. Kadar abu roti tawar dengan tepung sorgum terfermentasi $10 \%$ dan $20 \%$ adalah $0,823 \%$ dan $0,638 \%$ sedangkan roti tawar dengan tepung sorgum tanpa fermentasi $10 \%$ dan $20 \%$ memiki kadar abu $0,830 \%$ dan $0,718 \%$. Kadar serat produk roti tawar denga substitusi tepung sorgum cukup tinggi yaitu $3,375 \%$ dan $4,206 \%$ untuk substitusi $10 \%$ dan $20 \%$ tepung sorgum terfermentasi, sedangkan tanpa fermentasi kadar serat substitusi $10 \%$ dan $20 \%$ adalah $3,008 \%$ dan $3,873 \%$.

\section{DAFTAR PUSTAKA}

Anwar F., 1987. Diktat Analisa Zat Gizi. Jurusan Gizi Masyarakat Sumber Daya Keluarga. Fakultas Pertanian Institut Pertanian Bogor

Ibrahim, F.S., Babiker, E.E., Yousif, N.E., El-Tinay, A.H., 2005. Effect of fermentation on biochemical and sensory characteristics of sorghum flour supplemented with whey protein. Food Chemistry 92, 285-292

Hidayah, Z., 2010. Perubahan Mikrobiologis, Kimiawi, Fisik dan Kecernaan Pati secara In-Vitro Selama Fermentasi Sorgum Secara Spontan dan dengan Menggunakan Bakteri Asam Laktat. Tesis. Program Pasca Sarjana Universitas Gadjah Mada Yogyakarta

Lowe, B., 1943. Experimental Cookery. John Wiley and Sons Inc., New York.

Marsono, Y., 2004. Serat Pangan dalam Perspektif Ilmu Gizi. Pidato Pengukuhan Guru Besar. Universitas Gadjah Mada. Yogyakarta

Pranoto, Y., Anggrahini, S., Efendi, Z., 2013. Effect of natural and Lactobacillus plantarum fermentation on in-vitro protein and digestibilities of sorghum flour. Food Bioscience. www.elsevier.com. [9 mei 2013]
Rahardian, Z., 2010. Penentuan Harga dan Kebijakan Inventori pada Sistem Rantai Pasok PT. NIS dengan Model Permainan Stackelberg. Skripsi. Institut Teknologi Bandung

Winarno, 2002. Kimia Pangan dan Gizi. Penerbit PT Gramedia, Jakarta 